\title{
EGFL6 Gene
}

National Cancer Institute

\section{Source}

National Cancer Institute. EGFL6 Gene. NCI Thesaurus. Code C24360.

This gene plays a role in cell cycle and may play a role in cell growth. 